"We seek revelation with our eyes"1 : Engaging with school cultures through montage

"Nous cherchons de nos yeux une révélation": s'engager avec la culture scolaire par le montage

"Buscamos la revelación con nuestros ojos": inquiriendo en la cultura escolar mediante el montaje

\title{
lan Grosvenor
}

University of Birmingham, England

Inés Dussel

Centro de Investigación y Estudios Avanzados, México

Iveta Kestere

University of Latvia

\section{Karin Priem}

University of Luxembourg

\section{Lisa Rosén Rasmussen}

Aarhus University, Denmark

\section{Angelo Van Gorp}

Universiteit Ghent, Belgium

\section{ABSTRACT}

This article approaches the issue of school culture[s] through Walter Benjamin's project method of "montage." Five historians of education drawn from Europe and Latin America were presented with a series of school photographs and commentaries and were asked to use their knowledge and expertise to share their insights into past school culture[s].

Keywords: school cultures, photography, photobook, montage.

\footnotetext{
${ }^{1}$ Berger, J. (2013) Appearances: the Ambiguity of the Photograph, 98.
} 


\section{RESUME}

Cet article aborde la question de(s) culture(s) scolaire(s) par la méthode des «montages». L'auteur fit appel à cinq historiens de l'éducation de l'Europe et de l'Amérique latine. Il leur présenta une série de photos scolaires et communautaires et leur demanda d'utiliser leurs connaissances et leur expertise, puis de partager leurs idées sur les cultures scolaires du passé.

Mots-clés: cultures scolaires, la photographie, le photo-book, le montage.

\section{RESUMEN}

Este artículo aborda la(s) cultura(s) escolar(es) a través del método del "montaje" de Walter Benjamin. Se ha presentado una serie de fotografías escolares y comentarios a cinco historiadores de la educación de Europa y América Latina y se les ha pedido que usen sus conocimientos y experiencias para compartir su mirada sobre la(s) cultura(s) escolar(es) del pasado.

Palabras clave: culturas escolares, fotografía, álbum de fotos, montaje.

\section{Introduction}

The initial stimulus for this essay was a recent re-reading of the book Room Behaviour by the Canadian architect and author-artist, Rob Kovitz. Published in the late 1990s and composed of texts and images drawn from sources including decorating manuals, anthropological studies, performance art, crime scene photographs and literature, the book, through subjective editing and juxtaposition, offers a meditation on the "behaviour of rooms and the people that they keep" (Kovitz, 1997). Kovitz's book functions as both inventive montage and as a collaged "photobook." In the case of the former, it is possible to see in Room Behaviour a working through of Walter Benjamin's critical enterprise to make "visible" the "invisible." His contemporary Ernst Bloch said that Benjamin possessed:

A unique gaze for the significant detail, for what lies alongside, for those fresh elements which, in thinking and in the world, arise from here, for the individual things which intrude in an unaccustomed and non-schematic way, things which do not fit in with the usual lot and therefore deserve particular, intrusive attention (quoted in Smith, 1989, p. 340).

Benjamin rejected conventional narrative structures and thought to present his ideas in a form which obliterated all traces of the author:

Method of this project: literary montage. I needn't say anything. Merely show. I shall purloin no valuables, appropriate no ingenious formulations. But the rags, the refuse - these I will not inventory but allow, in the only way possible, to come into its own: by making use of them, (Benjamin, 1999, p. 460). 
There is an established practice where photography and publishing have gone "hand in hand," as Parr and Badger note in their history of the photobook:

The first great artistic statement in photography was not a single image but William Henry Fox Talbot's book The Pencil of Nature ... consisting of original prints accompanied by printed commentaries, it virtually defined the art of photography from the outset "as a picture-making art" but also as a methodology for gathering information, and a visual medium with a clear narrative imperative (Parr \& Badger, 2004, p. 10).

Ever since the birth of the photographic medium, photographers have been making, with or without text, bound collections of their works. Such books, commonly referred to today as "photobooks," usually have a particular subject or theme which is addressed primarily through an extended photographic essay. Some photobooks, like that of Fox Talbot, have texts that coexist with and complement the photographs, while in others, "words and pictures fight each other, in some cases positively, in others not" (Parr \& Badger, 2004, p. 9). As a photobook, Room Behaviour is comprised entirely of "found" photographs, which Kovitz selected, ordered, and appropriated, thereby giving "a new and potent voice to the material of others" (Parr \& Badger, 2004, p. 8).

In Parr and Badger's three volume history of the photobook, there are many examples of books focusing on children and adolescents, but there is only one example of an extended photographic essay on the subject of school, namely, The Valley Green 1951, edited by Jerry DeFalco and Joan Davison, which presents the story of the American Passaic Valley Regional High School, in Little Falls, New Jersey (Parr \& Badger, 2006, p. 194-195). Parr and Badger acknowledge that their history is not "the perfect survey" and that they were "partial and subjective in our selection and tastes" (Parr \& Badger, 2006, p. 5), and certainly there have been many more photographic essays on the subject of school: from Bernard Fergusson and László Moholy-Nagy's 1937 Eton Portrait to Ian Macdonald's more recent Eton (2007); from Robert Coles and Nicolas Nixon's study of three schools in Boston, School (1998), to David Williams' Pictures from No Man's Land (1985) with its focus on a school for girls in Edinburgh, Scotland; from Les Les Bancs de L'École (Kriegel, 2006) drawn from school images in the Roger-Viollet photographic archive to Paulo Catrica's visual essay on Portuguese schooling, Liceus (2005); and from Herb Snitzer's photographic documentary Living at Summerhill (1963) to Julian Germain's Classroom Portraits (2012), a "global typological record of the school environment and children experiencing it in the $21^{\text {st }}$ century" (Germain, 2012, p. 7). All of these photobooks constitute a rich but largely ignored source for historians of education. Nevertheless, the last twenty years have seen historians of education actively engaging with the "visual" or "pictorial turn" (see, for example, Joseph \& Burnaford, 1994; Margolis, 1999; Grosvenor, 1999, 2004; Depaepe \& Henkens, 2000; Burke, 2001; Rousmaniere, 2001; Margolis \& Rowe, 2004; Mietzner, Myers, \& Peim, 2005; Pozo 2006; Burke \& Grosvenor, 2007; Devlieger, 2008; Comas Rubí, 2010; Braster, 2011; Grosvenor \& Hall, 2012; Priem \& Thyssen, 2013; Collelldemont, 2014). This 
engagement and the claims made for the visual turn has also been the focus of some sharp debate, with Catteeuw et al. (2005), for example, concluding:

Our standpoint, is that the "pictorial turn", can only be useful in that it draws more attention to visual aspects of the reality of teaching and education, and so there is no need for infinite analyses about the "representation of education and teaching in visual sources", the source material is too limited in its content and number to be a representation of reality and can only really be used a complement to the textual sources with which it has to be interpreted (Catteeuw et al., 2005, p. 229).

What then of the present article?

Following Benjamin, "the method of this project" was montage. Six photographs were identified and circulated electronically to five historians of education. No contextual information was supplied. The photographs were all from the same archive in Birmingham, England, but from different collections, and the date range between the oldest and the newest image was fifty years. ${ }^{2}$ In addition, following Kovitz and the structure common to many photobooks, different short commentaries were chosen to sit alongside each image. The texts were drawn from a range of sources, philosophical essays, a teaching manual, a cultural studies essay, an autobiographical essay and a monograph on sensory history. The addition of the commentaries was used as a device to address the concerns of Catteeuw et al., but no guidance was given as to their purpose or use.

Liberated from their original contexts, the photographs were presented as "found objects." The properties of a photograph do not change, but over its material existence it accumulates and accrues different meanings as it enters into relationships with new contexts and audiences (Walker, 1997, p. 57). John Berger has pointed to an "abyss" between the moment recorded in a photograph and the moment of looking, saying that an instant photographed can only acquire meaning insofar as the viewer can read into it a duration extending beyond itself, and that it is when we find a photograph meaningful that we lend "it a past and a future" (Berger, 2013, p. 64). Given their disciplinary knowledge and expertise, the historians were simply asked to share what the photographs revealed to them about school culture[s]. The aim was to elicit a personal response to each photograph so as to give it a past and a future. No guidance was given as to how they should execute this task other than that they should use no more than 80 words. Finally, they were asked to reflect in general terms on the process of looking and seeking revelation with their eyes.

In Letter to a Young Educational Historian, António Nóvoa observed that "knowledge demands courage" and advised that the historian should know the rules of the discipline, "but never relinquish risk-taking and transgression" as "research is either creation or nothing" (Nóvoa, 2015, p. 49). The text which follows represents an act of risk-taking and

\footnotetext{
${ }^{2}$ Photographs 1, 3, 4, and 5 are from Birmingham Archives Photographic Collections, respectively LSH School Miscellany Pt1; WK B114702; LSH School Crafts; and LSH School Miscellany PT4. Photographs 2 and 6 are from the Paulo Catrica collection held by Birmingham Archives which were deposited as part of his Birmingham schools project. Thanks to the Archives and Paulo Catrica for permission to reproduce these photographs.
} 
transgression. Over the next twelve pages, the five historians of education "step inside the image," in a creative experiment (Rousmaniere, 2001, p. 111). Their thoughts can be read as continuing individual threads or as a collective response to each image. 


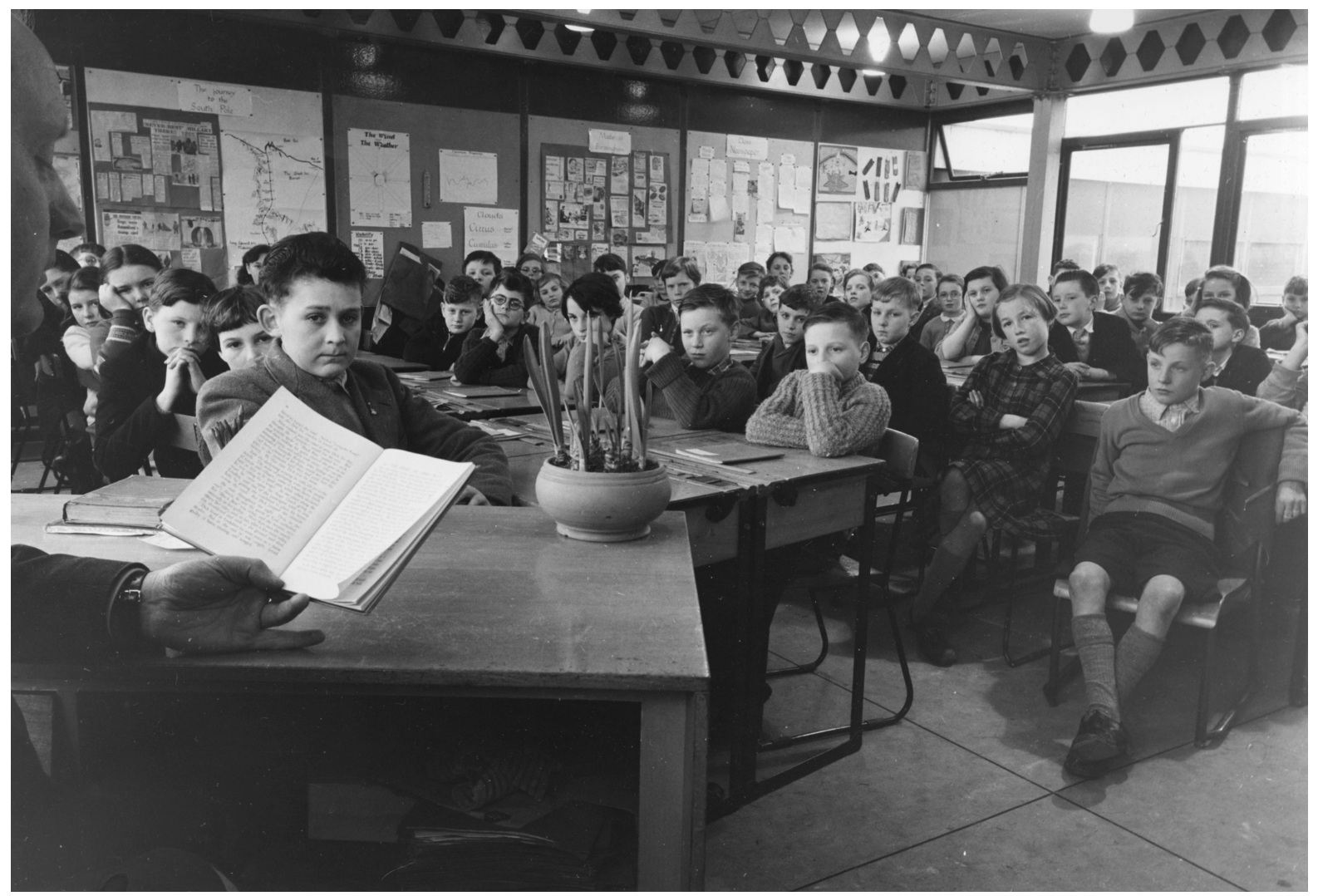

He opened a cupboard. Inside there were about fifty small bottles with ground stoppers, all numbered.

'Please, pick one.'

Morandi looked at him perplexed; he extended a hesitant hand and chose a small bottle.

'Open it and sniff it. What do you smell?'

Morandi inhaled deeply ...

'This would seem to be the smell of barracks.'

Montesanto in his turn sniffed. 'Not exactly,' he answered. 'Or at least not so for me. It is the odour of elementary school rooms; in fact, of my room in my school ... I understand that for you it's nothing: for me it's my childhood.

'I'm also preserving the photograph of my thirty-seven classmates in the first grade, but the scent from this small bottle is enormously quicker in recalling to my mind the interminable hours of tedium spent over the spelling primer; the particular state of mind of children ... during the terrifying suspense before the first dictation test. When I sniff it ... my innards are convulsed in just the way they were at the age of seven as I waited to be called up to be interrogated ...

Primo Levi, The Mnemogogues (1991). 
Inés Dussel: Smell is one of the "delicate, invisible threads" that weave society together, says Georg Simmel. The cramped classroom arouses olfactory memories in me as well. How did my school smell? Wooden floors and cheap painting, sweating bodies, worn-out uniforms and shoes flash out quickly, as much as the cart with mate cocido and a piece of bread that was cut in half each morning. Smells convey memories almost in slow motion: maybe that is why they swiftly connect to still images.

Iveta Kestere: Teacher interview: ${ }^{3}$ "The goal of any teacher, even though he may not admit it, is to drive in discipline. Only then, when everything is in order on that front, can he teach children with all of his soul" (Interview Nr. 9). The main figure in the classroom is the teacher - almost invisible, but physically very present - the centre of the pupils' line of sight as well as emotions. In the back, the "achievement wall" reminds me about the duty to learn diligently. As if on a front line, the pupils in the classroom are surrounded and disciplined and are taught with passion. Long live Foucault!

Karin Priem: Photography visually (re)presents the material evidence of educational spaces. Four objects, or things, of education are emphasised in the foreground of the image: a hand, a desk, a plant and a book. On a symbolic level, they represent teaching, discipline, development and knowledge, all of which aimed at a silent, listening audience. Literature, however, translates school culture into emotions, often by using the imaginative power of smells. Both image and text refer to the senses and the body: by presenting the silence of focused eyes and minds and by stressing school as an olfactory space that immediately triggers affects and memories of the omnipresence of discipline.

Lisa Rosén Rasmussen: Smell and memory. Levi's words remind me of the connection between memory and smell which is also referred to by Proust in Remembrance of Things Past. Smell as something that can link to past spaces packed with feelings and experiences, with collective and personal pleasures and traumas. Looking at the picture through Levi's text leads me to imagine the smell of the crammed classroom, of wet woollen socks and of smoke in the teacher's jacket. Infused by this smell I search the pupil's faces and their preoccupied stares, wondering about the many individual stories, which might have been shaped by this particular situation and taken on?

Angelo Van Gorp: To me, this "montage" of text and image is the most confusing one for at first the image doesn't match the text at all (as obviously intended). It ultimately was the confrontation between the old (the clothing, for instance) and the new (the setting and the building materials, for instance) in the photograph that evoked with me the odour of schools, being the smell of an old mimeograph that was standing in front of the class room, a materialized anachronism as it were. The "borders between present, past and future" continuously need to be "negotiated" (Bevernage \& Lorenz, 2013; Burke, 2005; Burke \& Grosvenor, 2011; Grosvenor, 2012).

\footnotetext{
${ }^{3}$ The quotes next to the photographs are taken from a total of 63 narrative interviews conducted with teachers, led by prof. Zanda Rubene, in 2008 and 2009. The respondents were asked to compare their professional experience under Soviet authoritarian rule with democratic rule after 1991. Interview transcripts are accessible in the Museum of Pedagogy at the University of Latvia.
} 


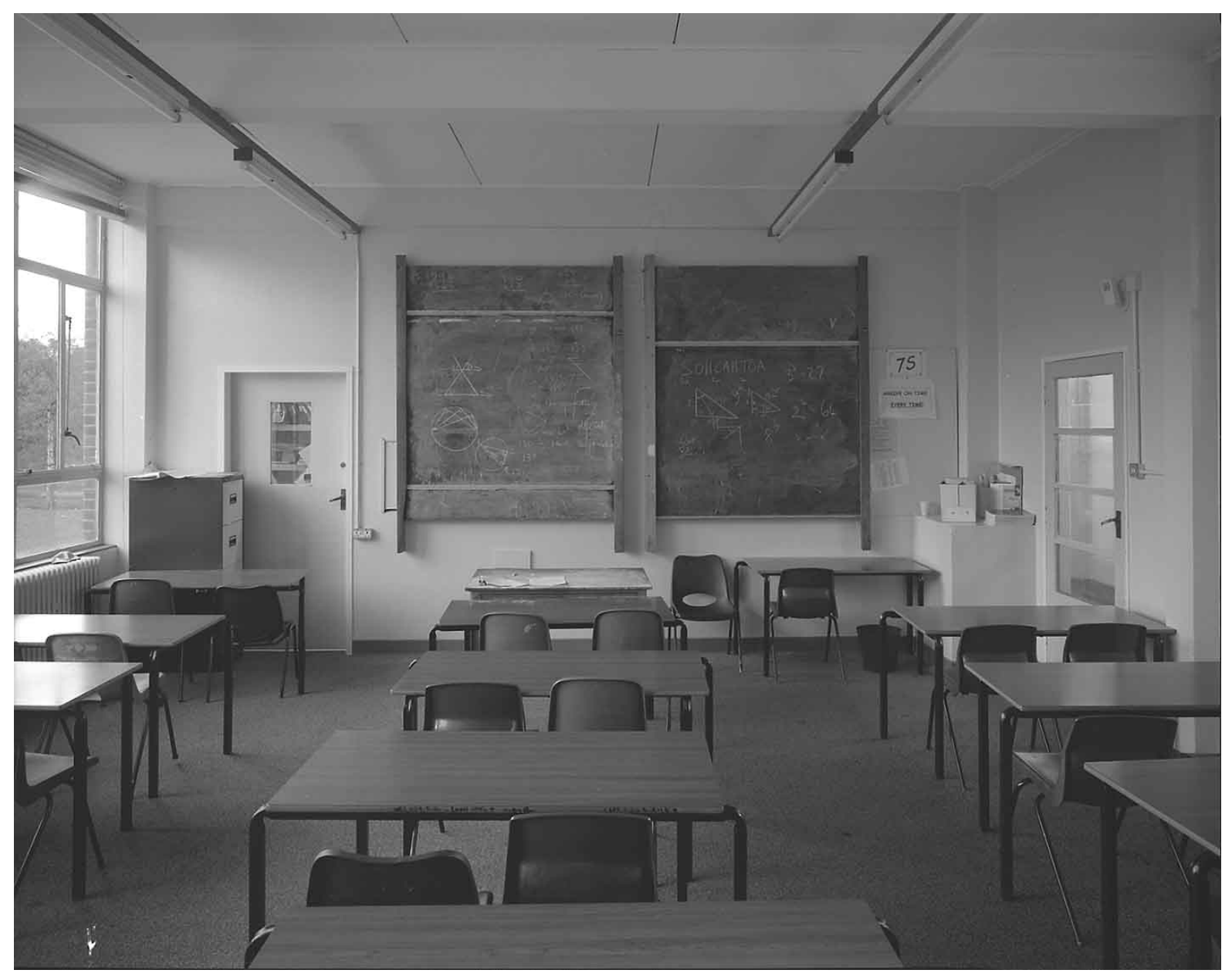

To repeat: visuality is always a synthetic act, involving, bodily, discursive, and material factors. A schoolchild scrutinizing a blackboard, a train driver obeying a signal, or an ophthalmologist examining a myopic eye: none of these acts of seeing was simply an effect of crushing, extrinsic normalization, technological discipline, or pure, unmediated human will. There acts of perception were, instead, the particular, relatively durable fusion of extrinsic agents (light, desk, sign, scope), forms of discourse (rules, tests, laws, norms) and physiological entities (eye, retina, optic nerve, brain, hands). Vision, as Merleau-Ponty argued, was essentially chiasmatic, or simultaneously, necessarily subjective and objective, and its government too should be regarded as a composite, multiple practice.

Chris Otter, The Victorian Eye. A Political History of Light and Vision in Britain, 1800-1910 (2008). 
ID: Look up! Here, pay attention! The silence of the image evokes the voices of command elicited by blackboards. As if they carried a perlocutionary force, they organize a particular disposition of bodies and attention. Easily associated with fixity, it is usually forgotten that blackboards were introduced in classrooms to make students move, walk, interact, and turn knowledge into a public, visible record. The classroom as a tactic of regulated freedom; and teachers and curriculum as choreographers of movements and talks.

IK: Teacher interview: "We survived almost solely with chalk and a desk, notebooks and writing implements. Children had a sense of responsibility towards the job of learning, and you could ask of the children responsibilities that, unfortunately, are not seen today" (Interview Nr. 16). The classroom - modest and orderly, just like church. This image remains in the collective memory, creating a sense of stability and safety in a disturbingly changing world. Yet, one chair in this classroom is placed in the "wrong" way. Is that a sign of resistance?

KP: The image displays the traditional order of a classroom, and the viewer immediately recalls how the students and the teacher should move and interact within this material and spatial setting. The blackboard symbolises the invisible teacher, who selects, gives structure and with his hand points to what is essential and should be learned. The tables and chairs orient the students towards this centre of the classroom. The materiality of the classroom thus proliferates a specific order of knowledge and underpins the hierarchy of educational space. However, once human agents appear on this modelled stage, their presence will add sounds, smells, movements, disturbances and interruptions.

LRR: Subjects of schooling. Otter's insistence on the body and on the subjective asks for pupils and teachers to inhabit the classroom in the photograph, becoming part of the clearcut and disciplinary lay-out portrayed here, and interacting with it. Anyhow, the strict order of the depicted classroom fixates the rhythm of listing detached elements in Otter's text. Thereby, Otter's argument of government as a composite and multiple practices is given a somewhat mechanical character.

AVG: The blackboard is the ordering principle of classroom arrangement (Donahue Wylie, 2012) as well as a metaphor for educational practices as is the school desk (Depaepe, Simon \& Verstraete, 2014; Herman et al., 2011). The position in the classroom transforms it into an altarpiece. By "wiping out" teacher and pupils, this image intensifies the tunnel vision the blackboard installs in the pupil. Textbooks and exercise books are mere auxiliaries to the blackboard. The only time the pupil is "allowed" to turn away the head from the blackboard is when he is punished and stands isolated in a corner, his eyes fixed on an empty wall (Herman et al., 2007). 


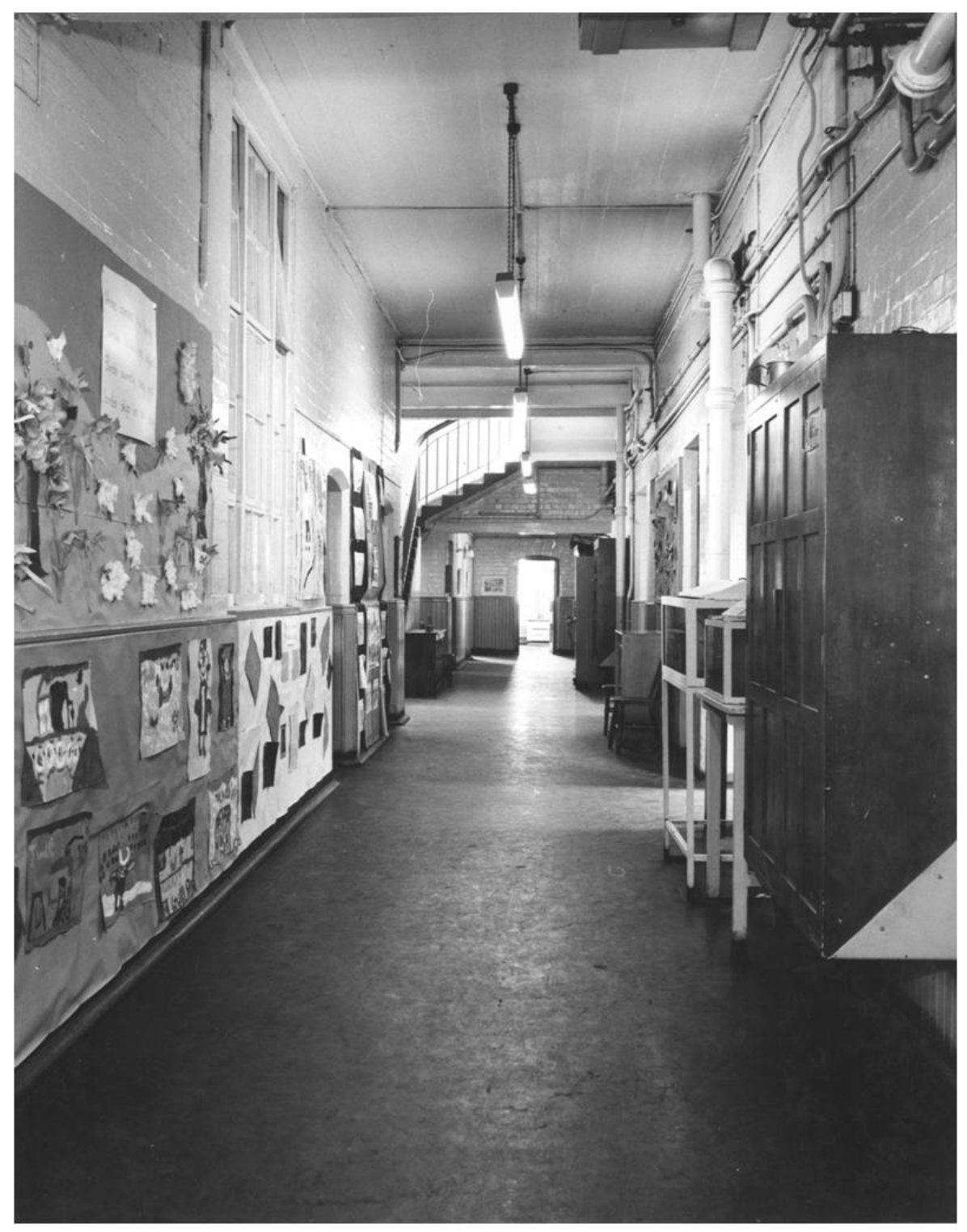

Between two peals of the bell lay the break, the second precipitating the shuffling, chattering uproar with which the mass of pupils streaming through only two doors, surged up the narrow stairway from floor to floor. These staircases I have always hated: hated when I was forced to climb them amid the herd, a forest of calves and feet before me, defencelessly exposed to the bad odours emanating from all the bodies pressing so closely against mine; hated no less when, arriving late, passing deserted corridors, I hastened up them quite alone to the very top, arriving breathless in the classroom. If that happened before the teacher's hand was on the door handle, even though he might be quite near, you got in unseen. But woe if the door was already shut!

Walter Benjamin, A Berlin Chronicle (1970). 
ID: Hate is seldom spoken in education, having been confined to the corner of bad feelings that have to be cleanly disposed of. Benjamin's words bring back the low passions that populate schools. Still, there is some mismatch with the picture. In these stairways it would have been difficult to run hastily to the upper floor, or to feel the odour of others. They seem a nice place to hide. But then, the saints act as masterly figures that dissuade playfulness. It looks like a place waiting for profanation. Maybe it is not that far from Benjamin's feelings after all.

IK: Teacher interview: "We had to make everything by ourselves and by hand. We could not just purchase them, go out and buy things. Then we had nothing; today there is everything (sigh)" (Interview Nr. 3). Teachers who wanted to make the world brighter and more beautiful started with the ugly and impersonal school corridors. Creativity personalized the space.

KP: Walter Benjamin describes school corridors as transitory spaces that mirror the rhythm of school life while being filled with sounds, smells, affects, random interactions and chaos. Even an empty corridor appears to be threatening, serving as a clear signifier of being late and undisciplined. As such, corridors are markers of time. The photograph shows a deserted corridor. This may remind viewers of the power of hidden surveillance - despite the open doors, the wall decorations and the display cabinets, which also symbolize transparency and creativity. Benjamin's autobiographical text, like the photograph, focuses on claustrophobia and control, omitting positive experiences of school life.

LRR: Space and affect. Spaces of passing, school corridors and stair wells as well as breaks seem to condense the dangers and fears of schooling. Brian Massumi writes about the body that "It moves. It feels. In fact it does both at the same time. It moves as it feels, and it feels itself moving" (Massumi, 2002, p. 1). Massumi's words echo Benjamin's memories about the fears and discomfort of climbing his school's stairwells before and between classes. Even the empty corridor is turned into a highly affective space. The empty space exposes the defenseless child being late for school and moving towards the classroom, but it can also from one moment to another be changed into a chaotic mess of moving and affective bodies.

AVG: Boys only, arms crossed, lined up and ready to enter the building. The teacher repeatedly snaps his fingers. Snap - the queue proceeds to the door. Snap - the queue proceeds to the staircase. Snap - the queue proceeds to the first floor. Snap - the queue proceeds to the class room door. All quiet on the school front. Snap - the queue enters the classroom, ready to desert but fearing the firing squad. The corridor is deserted even when it is not. 


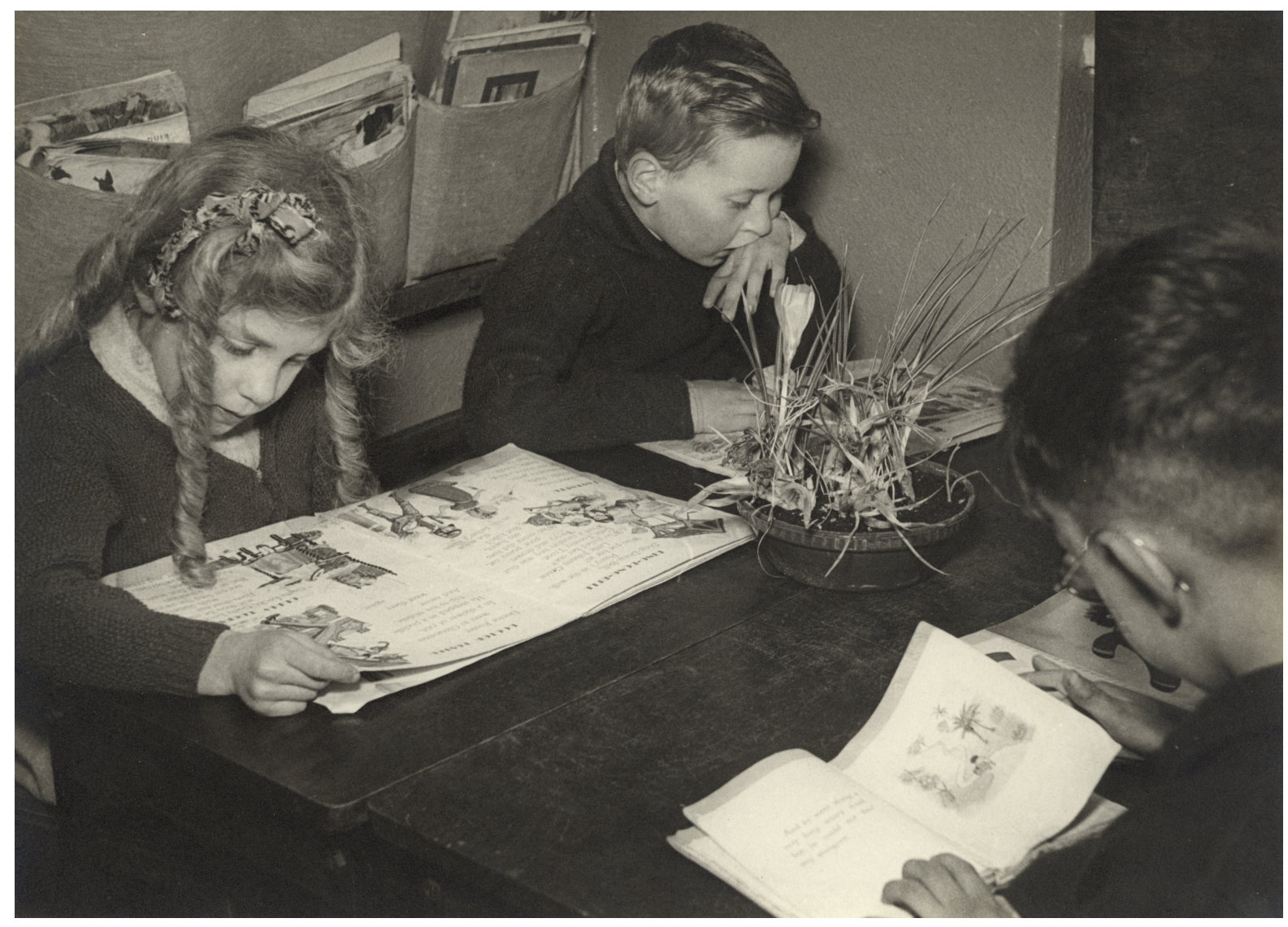

In the Janet and John books the greatest care has been taken to produce books that are attractive and satisfying as books. Paper of high quality has been chosen because only on good paper can print be clear and black, as it must be for children's eyes, and only on good paper can colours be reproduced as clearly and precisely as they should be.

Ample space has been allowed for the reading matter, since overcrowding the page is another cause of eye-strain. The type face chosen-is notably clear, well-formed and free from affectation. The illustrations have been drawn by artists who love and understand children. It is perhaps some awareness of this that makes children accept John and Janet as real children whose personalities and lives may emerge with their own.

The pictures are attractive to children. The artists have avoided eccentricity or appeal to adult sophistication. The subjects are treated with direct naturalness and good taste.

Rona Munro, A Teachers' Manual for use with The John and Janet Reading Course (1955). 
ID: If blackboards want a forward look, books cast the eyes downwards. This shift echoes Benjamin's observations about the dictatorship of the awe-inspiring perpendicular in ads and films, to which he opposes the horizontal plane that makes room for oblique, awry operations. But Munro's books are to be carefully designed so as to appear natural and unpretentious. Freedom to wander has to be captured and fixed. The history of school media is also that of the battles for children's attention.

IK: Teacher interview: "...right now there is no sense of wonder for a child. The child does not view anything as a wonder (...) There are many wonderful textbooks that did not exist earlier. Colourful, lots of information; but children don't want to think now. I really fear that the time will come when children will only have laptops (...) Children don't read, and that is terrible..." (Interview Nr. 15). Perennial propaganda photograph: the dream of all parents and teachers, children who read. That is, they are safe, controlled, and spend their time usefully.

KP: The history of books suggests that the shift from reading aloud to reading silently happened simultaneously with the rise of the printing business and the creation of libraries. Reading silently implies that the reader is alone with the text and able to reflect independently on what he or she reads. The text of the manual does not mention these effects of silent reading and instead focuses on the material quality of books and how it best supports what is deemed correct and efficient reading. Paradoxically, however, the image stresses the invisible and unpredictable thoughts of children reading silently.

LRR: Aesthetics of schooling. When Munro's text and the picture of books and pupils are read through each other, the aesthetics of teaching materials becomes a social and cultural construct involving artists, teachers and pupils as well as ideas, guidance literature and reading habits. It also involves the silence between the small readers and the atmosphere of the reading corner with its wooden table and the little plant, situating the books and their illustrations in a specific context somewhat removed from the artistic production involved. Thereby, the aesthetics of schooling is stretched well beyond the isolated artistic illustration on a piece of good paper.

AVG: The first thing popping up in my mind was that this image doesn't belong to the school cultures I remember. In my memory reading most often was a collective venture, leaving the enjoyment of reading to the private sphere at home. Attractive and nicely illustrated books nevertheless belonged to the school culture I have known for price books traditionally were the reward that marked the end of the school year and the start of the summer holidays (Depaepe et al., 2000; Herman et al., 2007). 


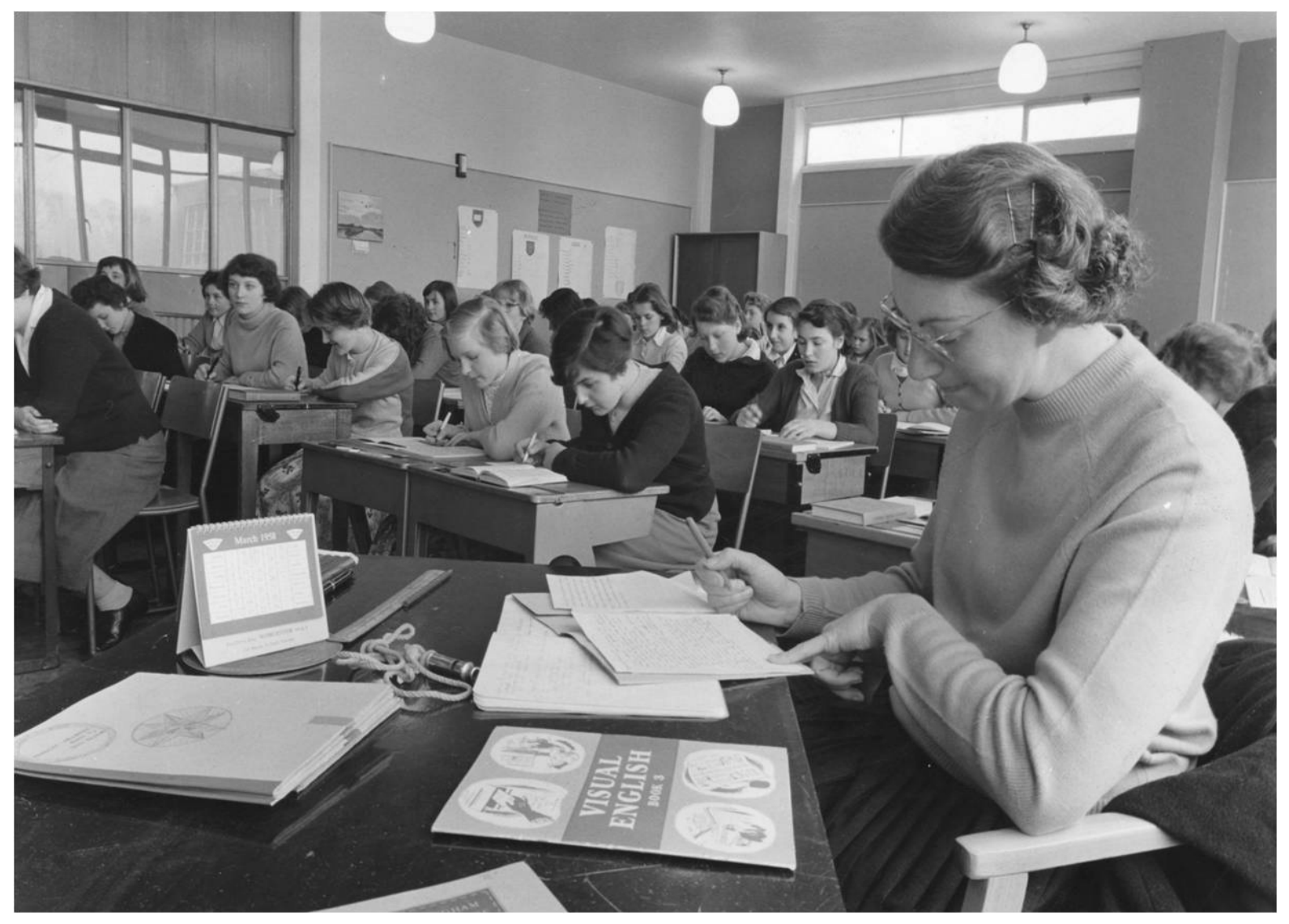

I tidy my work-table frequently. This consists of putting all the objects somewhere else and replacing them one by one ... This rearrangement of my territory rarely takes place at random. It most often corresponds to the beginning or end of a specific piece of work ... I dream of a work surface that is virgo intact: everything in its place, nothing superfluous, nothing sticking out, all the pencils well sharpened (but why have several pencils? I can see six merely at a glance!), all the paper in a pile, or better still, no paper at all, on an exercise book open at a blank page.

On the whole, I could say that the objects that are on my work-table are there because I want them to be ... there are objects useful for my work which aren't or aren't always there on my work-table, others which aren't immediately useful, or useful for some other purpose, or not useful at all but which are there all the same ... [it is] a way of marking out my space, a somewhat oblique approach to my daily practice, a way of talking about my work, about my history and my preoccupations, an attempt to grasp something pertaining to my experience ...

Georges Perec, Notes Concerning the Objects that are on My Work-table (1997). 
ID: The teacher's desk as a work-table. Perec's verbal images are detailed and precise. Juxtaposed to the photo, they set the teacher in motion: she leans down, adjusts her lenses, bites her lip, and writes down in a notebook (a student's? her own?). As Perec, she rearranges her books and papers, but is it her territory? Words and images point to the amount of work needed to make teaching happen, but they also make us wonder about whose writing, which work.

IK: Teacher interview: "Textbooks were the same throughout the country, and we knew exactly and clearly what we had to know! There was no waffling, like now. You had that book, that one... and that is what you had to know! (...) Every August, schools were controlled and we, as teachers, prepared a lot for this. Every classroom, every teacher's class had to have tables, materials, and various folders that were created according to strict requirements. And they poked into every folder and reviewed and looked! And teaching aids were either accepted or not. But I'm not saying that that was bad..." (Interview Nr. 47). The classroom is a child's world colonized by adults.

KP: The photograph shows what Perec describes as a tidy work-table. It becomes evident that similar processes of marking and ordering space take place in the classroom. Image and text interact and become entangled objects to think with and interrogate each other. The writer of the text may unconsciously repeat what he was taught at school, and the arrangement of things on his work-table may not at all be a result of his own free will. The literary text, when contrasted with the image, thus exemplifies how cultural patterns of school culture are subjectified.

LRR: Material and social orders. The photograph and Perec's text unfold an example of how social order can be seen as not only maintained but also challenged by the distribution of objects in space (Edensor, 2005, pp. 311-12). Perec's text points to the dream of a perfect and unspoiled order as well as of the (teacher's) work of holding everything in place by her continuous organisation of material objects. The photograph integrates the teacher's organisation of things in a time-specific example of how material and social orders seemingly work together. The slight disorder on the desk and among the pupils in the photo causes a small quiver in the order of the classroom. It points to the existence of this order, its fragility and its material and social complexity.

AVG: Although I see a tidy work-table, to me this image primarily is about time and not space, as the text would suggest. As time structuring objects, both the calendar and the whistle obviously refer to time. But also the teacher's posture, the face in particular relates with time. Is she correcting a student's work? Is she looking in her diary? Is she preparing the next exercise? She in any case is stealing time while the students concentrate on their work. 


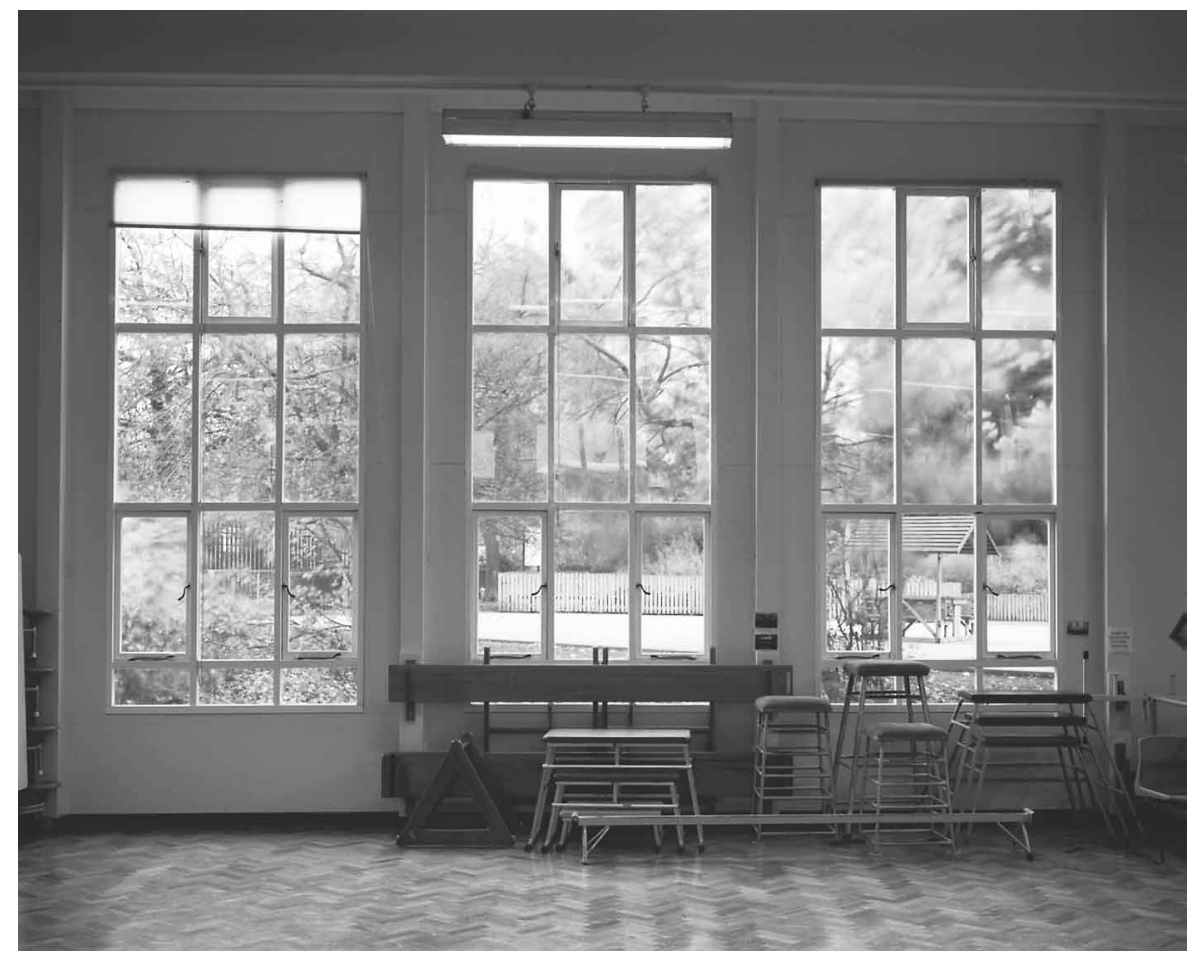

The photographic image signifies - communicates - meaning in a variety of different ways. It multi-accentual in the sense that it carries more than one meaning, supports more than one interpretation; also in the sense that its meaning cannot be finally fixed and so is always capable of being read different ways. The camera provides a sharp focus on what the image is manifestly about - the subject, centred in the foreground of the frame.

The still image arrests the flow of time, freezes the event, allowing us to look longer, get more out of it. What signifies is not the photographic text in isolation but the way it is caught up in a network of chains of signification that "overprint it," it's inscription into the currency of other discourses, which bring out different meanings. Its meaning can only be completed by the ways that we interrogate it.

Stuart Hall, "Introduction" to Paul Gilroy, Black Britain (2007). 
ID: Will the meaning of this image be completed by our questions? Maybe a starting point is to interrogate its stillness. Perhaps, as Trinh Minh-ha says, in stillness one may find true speed. How many people piled up the banks? What and who made this arrangement possible? Doesn't it feel like a pause waiting to be disrupted? Can we go outside and play? Maybe, again, our imagination is already too cinematic. Meaning will never be complete, but it can be saturated and overloaded.

IK: Teacher interview: "...I think that schools are rather closed places..." (Interview Nr. 64). Outside, on the other side of the school's windows, a different world revolves. But, without the school reality, this photograph would be nothing more than a banal winter scene.

KP: Stuart Hall suggests that images can be read and interpreted in multiple ways. It is true that photographs, as material and social agents, travel through time and space and become burdened with numerous interpretations, comments, affects and reflections. However, it may be useful to look at the material presence captured in a photograph. The photograph displays how social experiences are transformed into tangible things: that is, spaces for physical education and differently sized objects that specifically serve as agents of humanmaterial interactions.

LRR: Inside or outside? Do I want to fix my eyes on the gymnastic apparatus, on the light coming through the tall windows or on the bench outside? Do I wish to discuss the smell, the light or the material order of school? Do I wish to interpret discourses of discipline materialised in everyday school life? Stuart Hall's text requires me to reflect on where and how I look at and read the picture. First it makes my eyes flicker, slowly becoming more aware of the different perspectives it allows me to zoom in and out of. At the same time, the photo clearly frames the questions of the text for me and situates them in a specific context. Taken together, the text and the image ask how the photographic image can be read in various ways through the existing and upcoming discourses within the history of education.

AVG: This image communicates the tragedy of schooling. The foreground stands for order and discipline. The background symbolizes what is out of reach of children. Our gaze is attracted to the outside (the light) like clouds catch the pupils' eyes when they are dreaming away in the classroom. The door is blocked. Throw open doors and windows. Create mediators between the inside and the outside (Van Gorp, 2011, p. 518). The expanding classroom, vector of a school culture that could have prevented the child of running away? (Burke, 2009). 


\section{"We seek revelation with our eyes:" Concluding remarks (1)}

ID: Images and words have a problematic relationship. As Didi-Huberman (2003) says, they are two different modes of representation that have some points in common but that do not necessarily converge on the same meaning. We need words to confer meanings on images, but words do not contain or complete their meaning. Words, on the other hand, do not always fully translate into images. And words and images also evoke smells, tastes, sounds, touchings. Visual media are always already mixed. This experiment of rubbing images and texts against each other can illuminate some points in common, and also make us reflect on the possibilities and limits of each of these modes for understanding school culture. If reading (texts or images) is always putting signs in relation to other signs, then what relationships are we making with these signs? While for academics it is easier to reference texts to give a sense of where the words came from, images are more difficult to trace. Where did we get the idea that the image of a vacant classroom means dropout, failure, and loneliness? How is it that the faces of the first picture seem to convey tedium and not curiosity? Godard said that an image never comes alone, but that there are always two or three at hand. These images evoke other images that spring from our memories, but most likely came from the television, films, or newspapers, or were passed through textbooks or school albums. The modes of representation we use to reflect on schools are never pure, nor are they straightforward. They are saturated with meanings woven in more conversations than we can account for. To study school culture is to approach these signs that may seem obvious and try to make some of these conversations about their meanings visible. We might then begin to understand how scenes and objects got to be this way, and which other possibilities were and are still there.

IK: The photographer, remaining invisible, puts the world in order: “...image-makers try to control the interpretations given to their artifacts by the public by giving them cues of different kinds" (Burke, 2001: 182). Yet, text can destroy, transform, supplement, deny, and even give a different meaning to the world created by the photographer. This was my conclusion having realized how well texts about the reality of Soviet school are suited for photographs taken in another world. This compatibility makes us look differently upon common and comfortable texts created in the post-Soviet space: how much of that, which we considered signs of authoritarianism, is just school reality of a certain era on both sides of the Iron Curtain?

KP: It was a revealing exercise to look at the images and texts selected by Ian Grosvenor. I wondered how they were chosen and what other options there may have been. Since texts and images are cultural objects that interact with each other and with humans in many ways, alternative arrangements of images and texts would have resulted in different threads of meaning (Latour, 2005; Ingold, 2007). Both, images and texts are material and 
social objects to think with and to talk about while they travel though space and time (Appadurai, 1986). During their journeys they become entangled with various audiences, spaces and places, all of which contribute to the making of meaning(s). When images as presenters of material evidence become social objects, they usually trigger sounds and smells, they become objects of affect and bring countless memories to the surface (Edwards, 2012, 2006; Burke and Grosvenor, 2011; Grosvenor, 2012). Literary texts, however, are presenters of the structure of feeling (Williams, 1980). As such, they also describe affects and sensations that are experienced physically (Smith, 2007; Rodaway, 1994). In contrast, academic texts deliver a maximum of interpretation that claims to be objective. They model and standardize educational manifestations in a normative way sometimes by means of empirical data and numbers. This raises the question if academic texts are able to challenge educational norms, bridge the gaps and fill in the blanks that we may discover when looking at photography and literary texts (Priem, 2014). The phenomenon of school culture can be translated into and reflected in many genres photography, videos and films, paintings, literary texts, philosophical texts, empirically based academic texts etc. - each of which is equally important for the history of school culture. It is their interaction and their status as social objects that create a meshwork of meaning(s) (Ingold, 2008; Poos, 2015), a multidimensional, overlapping and entangled collective memory (Assmann, 2006) that pushes us to think further. As for photography and other objects of art, it is important to also look at their physical presence, their detachment from historical contexts, the phenomena and questions they present (Heidegger, 1927/2006; Gumbrecht, 2004; Pinney, 2005). One of these questions may be to analyse how social processes are translated and materialize into intelligible things (Simon, 2011).

LRR: Taken together, these texts and images reveal the complexity of school life as they point to issues connected to bodies, objects and materiality as well as vision, smell and affects. This happens in a process where texts and pictures are at first unintentionally and later deliberately read "through each other", as Karen Barad would phrase it. When reading texts and images through each other, specific aspects in both texts and images come to the fore. Out of this process something new might even be created, possibly giving new insights (Barad, 2007:29-30). When reading the image of the empty corridor and Walter Benjamin's written memoirs through each other, the empty space is chaotically filled with bodies, sounds and touch, with fear and discomfort. This leads me to ask questions about the affective dimension of school space. Moreover, texts and images seem to be (re-)situated in the process of diffraction. In the last example, Stuart Hall's text originally written as an introduction to Paul Gilroy's book about race is read through the photograph of the sunlit gym and thereby it is re-situated in the context of school and educational history. As revealed in my reflections on this final example, as a researcher I also play an important part in reading texts and images through each other (Barad, 2007: x-xi). Inevitably, my 
reading is influenced by my experience, my theoretical references and my position in the field of the history of education.

AVG: What struck me while reading the texts and looking at the images: it very much felt like an exercise into "walking down memory lane," although it not always referred to pleasant childhood memories. Obviously, this is about the visual. Scanning the images, my eye intuitively focused on particular details. Reading the texts, my eyes again spontaneously isolated particular notions. However, in both cases it linked up with memories related to my own time at school. As a consequence, all attention was either attracted to the image or to the text and rarely to the combination of both. It was the image that guided my gaze, the text that helped sorting my thoughts and phrasing the words.

Although I am using the word "spontaneously," I am aware of the bias that influences my "reading" of both texts and images. As a historian of education I like to use "visuals" not as mere illustrations but as "(re)sources," as objects of analysis and interpretation (Tosh, 2015, pp. 213-15). That bias results from my "knowing gaze" as both historical researcher and as someone familiar with visual methodologies (Grosvenor, 2010; Van Gorp, 2011). Talking about school cultures, here, nevertheless involves the intermingling of bias and memory. In this process I felt it was memory (the individual and often very personal experiences as well as the flow of time) that primarily led my gaze and forced me to what I am writing, taking into account the limited space of this paper.

For the record, I am 44 years old when writing these reflections, meaning that I went to school in the 1970s and 1980s. I am Belgian and only went to Catholic schools, reason why I identify the most with the second and the last image for it resembles the rigid school system of order and discipline I was used to. Actually, it is the three non-populated images that "touch" me the most. Reviving the school culture(s) in my memories, it is a certain "emptiness" that dominates memory lane, laying emphasis on the spatiality and infrastructure rather than on what happened in the classroom. It learns me two things: (1) spatiality not only is an intrinsic but also a crucial part of school culture (see, for instance, Depaepe et al., 2008; Viñao, 2001); and (2) that this exercise also is a "mental" process that cannot be disconnected from a certain "psychologization" of the relation between past and present that is carved into the stone called memory, a stone that - let it be clear -is subject to erosion (Tosh, 2015, p. 2). My reflections say as much about (Belgian) school culture(s) as it reveals about me. No wonder that in more than half of the cases, and out of a multitude of options, I ended up with references to discipline and order, as would undoubtedly have been the case if I would have been at school in the 1950s or 60s, and even beyond...

"We seek revelation with our eyes:" Concluding remarks (2) 
A photograph is only a fragment from the past, and as Sontag noted, "with the passage of time its moorings come unstuck. It drifts away into a soft abstract pastness, open to any kind of reading" (Sontag, 1979, p. 71). So what kind of readings have been presented here by our five risk-taking historians? Their individual short texts, like the extracts accompanying each image, in themselves constitute "extended captions," but like all captions they offer only one interpretation and cannot "permanently restrict or secure a picture's meaning" (Sontag, 1979, p. 108). At the same time, these texts are also the product of an intermingling of personal and professional history, of sense of self in time, of remembering and recollecting, and of bias in terms of theoretical preferences (the latter also representing an affirmation of the resilience of History of Education as an open discipline). If we acknowledge the complex issues which circulate around identity, memory and bias, the texts, nevertheless, illuminate some points in common. School culture is neither static nor singular. The texts, for all their meshwork of overlapping and entangled meanings, bring into sharp focus the interconnections and dynamic relationships between bodies, objects and the materiality of schooling as well as the affective dimension of school cultures. They cause us to reflect and push us to think further. The visual and textual sources we use to tell our stories of the past are in turn the product of people who inhabited their own cultural contexts and perspectives. It follows that to engage with the past we have to enter into a dialogue with those people and their contexts.

Finally, one of the reviewers on reading the manuscript was reminded of Roger Chartier's introduction to Patrick Boucheron's "leçons inaugurales" at the Collège de France, where he employed the term "indiscipline":

Boucheron allows himself unusual freedoms in the discipline; for example, making up for the silences of the archives by constructing plausible stories, or probable, in this case, of an encounter between the two men, which is not supported by any document. It is this discrepancy regarding the rules that Icall indiscipline. Boucheron shows what historical knowledge can expect from a reasoned use of the imagination while he indicates, in the negative, the limits or the fragilities of the historian's discourse (Chartier, 2015). ${ }^{4}$

The extent to which this article is an encounter with "indiscipline", and one that makes "visible" the encoded "invisible", gives "a new and potent voice to the material of others" and disrupts traditional narratives of school history and culture, in the end, is for the reader to judge, and to reflect upon.

\footnotetext{
${ }^{4}$ Boucheron s'autorise des libertés inhabituelles dans la discipline: par exemple, combler les silences des archives par la construction d'un récit plausible, ou probable - en ce cas, celui d'une rencontre entre les deux hommes, que n'atteste aucun document. C'est cet écart par rapport aux règles que je nomme indiscipline. II montre ce que la connaissance historique peut attendre d'un usage raisonné de l'imagination en même temps qu'il indique, comme en négatif, les limites, ou les fragilités du discours de l'historien (Chartier, 2015).
} 


\section{References}

Appadurai, A. (Ed.). (1986). The Social Life of Things: Commodities in Cultural Perspective. Cambridge: Cambridge University Press.

Assmann, A. (2006). Memory, Individual and Collective. In R. E. Goodin, and C. Tilly (Eds.), The Oxford Handbook of Contextual Political Analysis (pp. 210-24). Oxford: OUP.

Barad, K. M. (2007). Meeting the Universe Halfway: Quantum Physics and the Entanglement of Matter and Meaning. Durham: Duke University Press.

Benjamin, W. (1978). One-Way Street. In W. Benjamin, One Way Street and Other Writings (pp. 61-63). (trans. E. Jephcott and K. Shorter). London: Verso (originally appeared in 1928).

Benjamin, W. (1999). The Arcades Project (trans. H. Eiland and K. McLaughlin). Cambridge, Mass.: Belnapp Press.

Berger, J. (2013). Appearances: The Ambiguity of the Photograph. In G. Dyer (Ed.), John Berger Understanding a Photograph. London: Penguin Books, 61-98.

Braster, S. (2011). Educational Change and Dutch Classroom Photographs. In S. Braster, I. Grosvenor, and Pozo, M. M. (Eds.), The Black Box of Schooling (pp. 21-38). Bruxelles: Peter Lang.

Burke, C. (2001). Hands-on History: Towards a Critique of the Everyday. History of Education, 30 (2), 191-201.

Burke, C. (2005). Contested Desires: The Edible Landscape of School. Paedagogica Historica, 41 (4-5), 571-587.

Burke, C. (2009). "Inside Out”: A Collaborative Approach to Designing Schools in England, 1945-1972. History of Education, 45 (3), 421-433.

Burke, C., and Grosvenor, I. (2007). The Progressive Image in the History of Education: Stories of two Schools. Visual Studies, 22 (2), 155-168.

Burke, C., and Grosvenor, I. (2011). The Hearing School: An Exploration of Sound and Listening in the Modern School. Paedagogica Historica, 47 (3), 323-340.

Burke, P. (2001). Eyewitnessing. The Uses of Images as Historical Evidence. Ithaca, New York: Cornel University Press.

Bevernage, B., and Lorenz, C. (2013). Breaking up Time: Negotiating the Borders between Present, Past and Future. Storia della storiografia: Rivista internazionale, 63 (1), 3150.

Catteeuw, K., Dams, K., Depaepe, M., and Simon, F. (2005). Filming the Black Box: Primary Schools on Film in Belgium, 1880-1960: A First Assessment of Unused Sources. In U. Mietzner, K. Myers, and N. Peim (Eds.), Visual History. Images of Education (pp. 203231). Bern: Peter Lang.

Catrica, P. (2005). Liceus. Lisboa: Assírio \& Alvim.

Chartier, R. (2015). Introduction. Retrieved from: http://books.openedition.org/cdf/4505. Accessed September, 2016. 
Coles, R., and Nixon, N. (1998). School. Boston: Little, Brown and Company. Collelldemont, E. (Ed.). (2014). Investigar La Història de L'Educació amb Imatges. Vic: MUVIP. Comas Rubí, F. (Ed). (2010). Fotografia i història de l'educació. Educació i Història: Revista d'Història de l'Educació, 15.

Depaepe, M., and Henkens, B. (Eds.). (2000). The Challenge of the Visual in the History of Education. Paedagogica Historica, 36.

Depaepe, M., et al. (2000). Order in Progress: Everyday Education Practice in Primary Schools - Belgium, 1880-1970. Louvain: Leuven University Press.

Depaepe, M. et al. (2008). About Pedagogization: From the Perspective of the History of Education. In P. Smeyers, and M. Depaepe (Eds.), Educational research: The educationalization of social problems (pp. 13-30). Dordrecht: Springer.

Depaepe, M., Simon, F., and Verstraete, P. (2014). Valorising the Cultural Heritage of the School Desk through Historical Research. In P. Smeyers, and M. Depaepe, (Eds.), Educational Research: Material Culture and its Representation (pp. 13-30). Dordrecht: Springer.

Devlieger, P., Grosvenor, I., Simon, F., Van Hove, G., and Vanobbergen, B. (2008). Visualising Disability. Paedagogica Historica, 44 (6), 747-60.

Didi-Huberman, G. (2003). Imágenes, pese a todo. Memoria visual del Holocausto (trans. M. Miracle). Barcelona: Paidós.

Donahue Wylie, C. (2012). Teaching Manuals and the Blackboard: Accessing Historical Classroom Practices. History of Education, 41 (2), 257-272.

Edensor, T. (2005). Waste Matter - The Debris of Industrial Ruins and the Disordering of the Material World. Journal of Material Culture, 10 (3), 311-32.

Edwards, E. (2006). Photographs and the Sound of History. Visual Anthropology Review, 21, 27-46.

Edwards, E. (2012). Objects of Affect: Photography beyond the Image. The Annual Review of Anthropology, 41, 221-234.

Fergusson, B., and Moholy-Nagy, L. (1937). Eton Portrait. London: John Miles.

Germain, J. (2012). Classroom Portraits. London: Prestel.

Grosvenor, I. (1999). On Visualizing Past Classrooms. In I. Grosvenor, M. Lawn, and K. Rousmaniere, (Eds.), Silences and Images: The Social History of the Classroom (pp. 83104). New York: Peter Lang.

Grosvenor, I. (2010). The School Album: Images, Insights and Inequalities. Educació $i$ Història: Revista d'Història de l'Educació, 15, 149-164.

Grosvenor, I. (2012). Back to the Future or Towards a Sensory History of Schooling. History of Education, 41 (6), 675-687.

Grosvenor, I., Lawn, M., Novoa, A., Rousmaniere, K., and Smaller, H. (2004). Reading Educational Spaces. Paedagogica Historica, 40 (3), 315-332.

Grosvenor, I., and Hall, A. (2012). Back to School, from a Holiday in the Slums!: Images, Words and Inequalities, Critical Social Policy, 32 (1), 11-30. 
Gumbrecht, H. U. (2004). Production of Presence. What Meaning Cannot Convey. Stanford, Calif.: Stanford University Press.

Heidegger , M. (1927/2006). Sein und Zeit (19th ed.). Tübingen: Max Niemeyer.

Herman, F. et al. (2007). Punishment as an Educational Technology: A Form of Pedagogical Inertia in Schools? In P. Smeyers, and M. Depaepe (Eds.), Educational Research: Networks and Technologies (pp. 203-219). Dordrecht: Springer.

Herman, F. et al. (2011). The School Desk: From Concept to Object. History of Education, 40 (1), 97-117.

Ingold, T. (2007). Lines: A Brief History. Milton Park, Abdingdon: Routledge.

Ingold, T. (2008). Bindings Against Boundaries: Entanglements of Life in an Open World. Environment and Planning, A 40, 1796-1810.

Joseph, P. B., and G. E. Burnaford (1994). Images of Schoolteachers in Twentieth Century America: Paragons, Polarities, Complexities. Mahwah, New Jersey: Lawrence Erlbaum.

Kriegel, F. (Ed.). (2006). Les Bancs de L'École. Paris: Hachette Livre.

Kovitz, R. (1997). Room Behaviour. Toronto, Canada: Insomniac Press.

Latour, B. (2005). Reassembling the Social: An Introduction to Actor-Network-Theory. Oxford: Oxford University Press.

Macdonald, I. (2007). Eton. Windsor: Ian Macdonald.

Margolis, E. (1999). Class Pictures: Representations of Race, Gender and Ability in a Century of School Photography. Visual Sociology, 14, 7-38.

Margolis, E., and Rowe, J. (2004). Images of Assimilation: Photographs of Indian Schools in Arizona. History of Education, 33 (2), 199-230.

Massumi, B. (2002). Parables for the Virtual: Movement, Affect, Sensation. Durham: Duke University Press.

Mietzner, U., Myers, K., and Peim, N. (Eds.). (2005). Visual History. New York: Peter Lang.

Minh-Ha, Trinh T. (2005). The Digital Film Event. New York: Routledge.

Nóvoa, A. (2015). Letter to a Young Educational Historian. Historia y memoria de la educación, 1, 47-58.

Parr, M., and G. Badger (2004). The Photobook, volume I. London: Phaidon Press.

Parr, M., and G. Badger (2006). The Photobook, volume II. London: Phaidon Press.

Parr, M., and G. Badger (2014). The Photobook, volume III. London: Phaidon Press.

Pinney, C. (2005). Things Happen: Or, from which Moment Does This Object Come? In D. Miller (Ed.), Materiality (pp. 256-271). Durham: Duke University Press.

Poos, F. (2015). Hidden Images. The Making of a National Family Album. Unpublished Dissertation, De Monfort University, Leicester, UK.

Pozo, M. M. (2006). Imágenes e historia de la educación: construcción, reconstrucción y representación de las prácticas escolares en el aula. Historia de la Educación, 25, 291315. 
Priem, K. (2014). Visual, Literary, and Numerical Perspectives on Education: Materiality, Presence, and Interpretation. In P. Smyers, and M. Depaepe (Eds.), Educational Research: Material Culture and Its Representation (pp. 53-69). Dordrecht: Springer.

Priem, K., and G. Thyssen (2013). Puppets on a String in a Theatre of Display? Interactions of Image, Text, Material, Space and Motion. Paedagogica Historica, 49 (6), 828-845.

Rousmaniere, K. (2001). Questioning the Visual in History of Education. History of Education, 30(2), 109-116.

Simmel, G. (1997). Sociology of the Senses. In D. Frisby, and M. Featherstone (Eds.), Simmel on Culture (pp. 109-19). London: Sage. (Originally appeared in 1907).

Simon, J. (2011). Neomaterialism. Berlin: Sternberg Press.

Smith, G. (1989). (Ed.), Walter Benjamin: Philosophy, Aesthetics, History. Chicago: University of Chicago Press.

Sontag, S. (1979). On Photography. London: Penguin Books.

Snitzer, H. (1964). Living at Summerhill. Toronto: Collier Macmillan.

Tosh, J. (2015). The Pursuit of History: Aims, Methods and New Directions in the Study of History. London and New York: Routledge.

Van Gorp, A. (2011). The Decroly School in Documentaries (1930s-1950s): Contextualising Propaganda from Within. Paedagogica Historica, 47 (4), 507-523.

Viñao, A. (2001). Do Education Reforms Fail? A Historian's Response. Encounters on Education, 2, 27-47.

Williams, D. (1985). Pictures from No Man's Land. Edinburgh: Waterfront.

Williams, R. (1980). The Long Revolution (5th ed.). Harmondsworth/Middlesex: Penguin. 